\title{
IKA소
}

JKAP (Jurnal Kebijakan dan Administrasi Publik) Vol.21 (1), May 2017, 29-39

ISSN 0852-9213 (Print), ISSN 2477-4693 (Online) Available Online at https://journal.ugm.ac.id/jkap

\section{Far From Fire: \\ The Service Delivery Quality Gap Plaguing Indonesian Ports}

\author{
Wayu Eko Yudiatmaja \\ Department of Public Administration \\ Faculty of Social and Political Sciences, Universitas Maritim Raja Ali Haji \\ wayuguci@umrah.ac.id \\ Alfiandri \\ Department of Public Administration \\ Faculty of Social and Political Sciences, Universitas Maritim Raja Ali Haji \\ alfiandrikepri@gmail.com \\ Rahmat Hidayat \\ Undergraduate of Public Administration \\ Faculty of Social and Political Sciences, Universitas Maritim Raja Ali Haji \\ alcantara.1693@gmail.com
}

\begin{abstract}
This study analyzes the gap between expected and perceived services by ship passengers at the Sri Bayintan Port, Kijang, Riau Archipelago. The purpose of the paper is to examine the gap between expected and perceived service delivery by ship passengers in the Sri Bayintan Port. To test the service gap, ServQual variables as postulated in Parasuraman, Zeithaml \& Berry (1988) were used. The variables include tangibility, reliability, responsiveness, assurance, and empathy. Data were collected using a sample of 98 passengers, who were chosen at random. Research results showed that there is a significant difference between expected and perceived service delivery among passengers who use Sri Bayintan port. In particular, findings of this study showed that passengers were not satisfied with the quality of service delivery they received in Sri Bayintan Port.
\end{abstract}

Keywords: port service, quality gap, ServQual 


\section{INTRODUCTION}

Today the government faces pressure to constantly increase the quality of its service delivery (Shah, 2005; Pramusinto, 2006; Widaningrum, 2007; Hartley \& Skelcher, 2008; Yudiatmaja, 2012). Three mainstream theoretical perspectives characterize extant literature on public administration, which can be used to analyze service delivery quality interalia: old public administration, new public management), and new public service paradigm. Classic public administration perspective posits the notion that a state can establish and adopt a rigid and standardized system to foster efficiency in public service delivery (Taylor, 1947; White, 1926; Willoughby, 1927). Meanwhile, based new public management perspective, the government can adopt free market mechanism in delivering services to society. Thus, the focus is on market oriented delivery and customer satisfaction, rather than standards and rules (Osborne \& Gaebler, 1992; Ferlie, Ashburner, Fitzgerald, \& Pettigrew, 1996; Osborne \& Plastrik, 1997; Kettl, 2000). To the contrary, new public management paradigm, the government is expected to focus on meeting the needs and requirements of its citizenry (Denhadrt \& Denhardt, 2007).

Researchers and practitioners have for long paid serious attention to the quality of delivery (Grönroos, 1984). In the context of a business organization, the quality of delivery is the main factor that guarantees winning the competition. Business environment which is characterized by high stiff competition demands every organization to fulfil the entirety of customer needs and expectations (Zeithaml, 2002; Dick \& Dick, 2007). It is not impertinent to say that a company that survives the competition is one that has the ability to provide excellent services and meet customer needs in the best way possible. Meanwhile, in the context of a public sector organization, the quality of delivery of goods and services does not have strong correlation with the existence of the organization as the government does not depend directly on users of public services (Murray, 1975; Rainey, Backoff, \& Levine, 1976; Lachman, 1985;Rainey \& Bozeman, 2000; Boyne, 2002; Moulton \& Wise, 2010).
Today, the quality of service delivery plays a crucial role in many service industries. This is attributable to the fact that quality of service delivery served as an effective differentiator of goods and services that are provided by various providers. To that end, it is not surprising that organizations which use to compete on the basis of low prices and sophisticated technology, are currently developing business strategies that are underpinned by the desire to provide quality service delivery to consumers. Quality service delivery is premised on the ability to fulfil all the expectations of users of goods and services. Thus, quality delivery can be assessed by comparing perceived delivery and expected service delivery (Parasuraman, Zeithaml, \& Berry, 1985, 1988, 1991, 1993; Zeithaml, Parasuraman, \& Berry, 1990; Berry et al., 1994; Brysland \& Curry, 2001).

The main purpose of this research is to assess the quality of service delivery at the ship harbor that is under the management of PT Pelayaran Indonesia (Pelindo) I, Sri Bayintan Port, Kijang, Kepulauan Riau. Several factors influenced the choice of Sri Bayintan harbor for this research. First, Sri Bayintan harbor as sea port in Kepulauan Riau province plays an important role in sea transportation for the local community. This is due to the fact that Sri Bayintan Port is a major player in the transportation of passengers that travel across islands every week in the province using PT Pelni large ships (Table 1). Secondly, Sri Bayintan port handles many seafarers to and from various locations, within Kepulauan Riau province (Anambas, Natuna, and Tambelan) and across provinces in Indonesia, such as West Kalimantan, Central Java, and East Nusa Tenggara.

This research contributes to extant literature on public service management by examining the gap in service delivery in the public sector in Indonesia in general and harbor service delivery in particular. Research on the quality service delivery gap in harbor service provision, which has not received as much attention as other aspects of public service delivery by researchers. There is a lot empirical research in business organization that compares consumer expected and perceived public service delivery 
Wayu Eko Yudiatmaja, Alfiandri and Rahmat Hidayat — Far from Fire: The service delivery....

Table 1. Data of Passengers Sri Bayintan Port (2010-2015)

Source: Data on passengers PT Pelindo I

\begin{tabular}{cc}
\hline Year & Number of Passengers \\
\hline 2010 & 61.496 \\
2011 & 62.419 \\
2012 & 54.271 \\
2013 & 60.106 \\
2014 & 68.087 \\
2015 & 65.461 \\
\hline
\end{tabular}

(Parasuraman, Zeithaml, \& Berry, 1985, 1988; Brown, Churchill, \& Peter, 1993; Najjar \& Bishu, 2006). Meanwhile, with regards to public sector organizations in other countries, there is a lot of research that compared expected and perceived public service delivery quality (McKoy, 2004; Agus, Barker, \& Kandampully, 2007; Ansah, 2008; Rhee \& Rha, 2009). Nonetheless, this research is still important given the fact that the dynamics and context of public sector organizations in Indonesia is starkly different from countries that were studied in previous research on the topic.

The research question for this study is to determine the perceived service delivery and expected service delivery in Sri Bayintan passenger terminal. The research delved into the quality of services passengers received and quality of services passengers expected from PT Pelindo I as the operator of Sri Bayintan port viewed from the dimension of reliability, responsiveness, assurance, empathy, and tangibility. Subsequently, this research also conducted analysis of the level of satisfaction of passengers with service delivery in Sri Bayintan port.

ServQual is one of the methods used in measuring the quality of service delivery. The model was developed and introduced by Parasuraman, Zeithaml, \& Berry (1985) to measure the quality of service delivery in marketing organizations in the United States of America. Initially Parasuraman, Zeithaml, \& Berry, (1985) formulated 10 variables that were considered to determine the quality of service delivery. The variables consisted of, reliability, responsiveness, competence, access, courtesy, communication, credibility, safety, knowledge, and tangibility. Later on, Parasuraman, Zeithaml, \& Berry (1988) simplified the dimensions used in ServQual into 5 variable, which include reliability, responsiveness, assurance, empathy, and tangibility. According to Parasuraman, Zeithaml, \& Berry (1988) the quality of service delivery can be gauged from a comparison of perceived quality and objective quality.

The ServQual Model, which was Parasuraman, Zeithaml, \& Berry (1985) developed has been used to test service delivery quality in business organizations. Lately the model has also been adopted to measure the quality of service delivery in public sector organizations. The model was declared fit and proper for public sector organizations (Donnelly et al., 1995; Wisniewski \& Donnelly, 1996; Orwig, Pearson, \& Cochran, 1997; Rowley, 1998; Brysland \& Curry, 2001; Wisniewski, 2001; Curry \& Sinclair, 2002; Pérez et al., 2007; Yousapronpaiboon, 2014). Moreover, the ServQual model can be adopted to measure the gap between expected service delivery and perceived service delivery for service users. What is equally important for this research is that the ServQual model can also be used to analyze the quality of service delivery in public sector organizations.

According to Parasuraman, Zeithaml, $\&$ Berry (1988) the quality of service delivery among other variables is influenced by reliability, responsiveness, assurance, empathy, and tangibility. Previous studies on private sector organizations showed the existence of a gap between expected and perceived quality service delivery for consumers (Parasuraman, Zeithaml, \& Berry, 1988, 


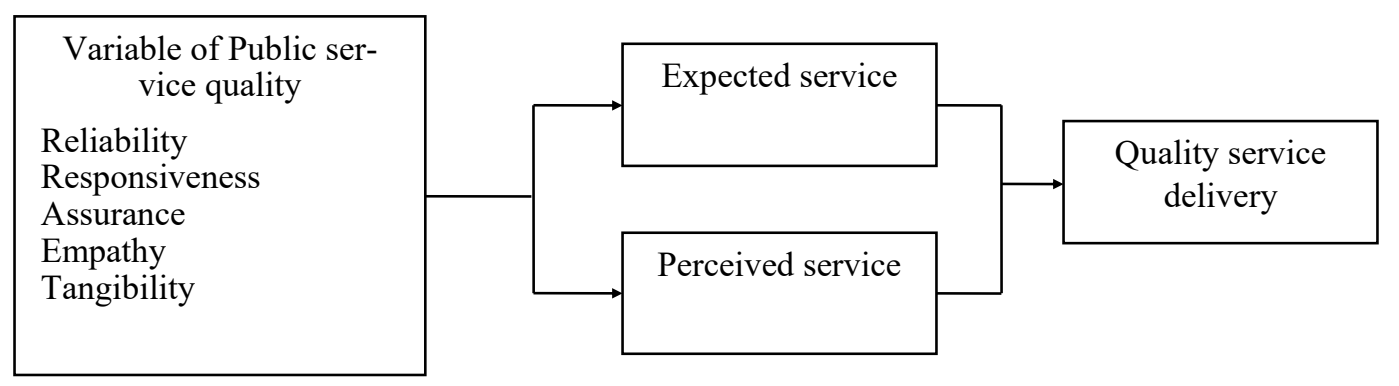

Figure 1. Conceptual Framework

1991; Brown \& Swartz, 1989; Malhotra et al., 2005; Pinar \& Eser, 2008). In a study that was conducted on a public sector organization also showed the existence of a gap between expected and perceived service delivery quality among service users (Donnelly et al., 1995; Wisniewski \& Donnelly, 1996; Orwig, Pearson, \& Cochran, 1997; Agus,Barker, \& Kandampully, 2007). Meanwhile, several studies on public sector organizations in advanced countries found that the quality pf service delivery in government organizations is still relatively low (Clements, 2001; Kim, 2004; Giannoccaro et al., 2008). Consequently, members of society or public expressed dissatisfaction with service delivery of public sector organizations. Previous studies on service delivery in developing countries also found evidence of low quality service delivery (Jakka, 2004; Lewis \& Pattinasarany, 2009; Yousapronpaiboon \& Johnson, 2013b; Yousapronpaiboon \& Johnson, 2013; Yousapronpaiboon \& Johnson, 2013). In light of the foregoing, the hypotheses for this research are as follows:

H1 There is a gap between passenger expectations of and perception about services received

H2 Passenger are dissatisfied with service delivery of $\mathrm{PT}$ Pelindo I in its capacity as the manager of Sri Bayintan Kijang port

The conceptual framework of this research (Figure 1) is a modified version of the model developed by Parasuraman, Zeithaml, \& Berry (1985). The quality of service delivery constitutes a comparison between expected and perceived service delivery by passengers. Expected and perceived service delivery is influenced by reliability, responsiveness, assurance, empathy, and tangibility.

\section{RESEARCH METHODS}

The research used a quantitative research design, with a survey serving as the data collection technique. Data were collected using a questionnaire which was developed in accordance with items that are included in a ServQual model which was developed by Parasuraman, Zeithaml, \& Berry (1988). Items on the questionnaire compare expected service delivery and perceived service delivery of consumers. The choice of the ServQual model was based on the fact that the model has been subjected to tests in accordance with research on service quality delivery conducted on ports in a number of countries (Ugboma, Ibe, \& Ogwude, 2004; Ugboma et al., 2007; Pantouvakis \& Lymperopoulos, 2008; Pantouvakis, Chlomoudis, \& Dimas, 2008). Dimensions of ServQual model that were used included; reliability dimension (5 items), responsiveness (5 items), assurance (5 items), empathy (5 items), and tangibility (5 items). The study used Likert scale as a measuring instrument, that consisted of 5 subscales, that ranged from very good (5), good (4), adequate (3), not good (2), and bad to poor (1). The population for the research was all passengers who use Sri Bayintan passenger terminal. Meanwhile the sample of the research was determined on the basis of Slovin formulation (Tejada \& Punzalan, 2012) with a significant error of $10 \%(p \leq 0.01)$. Acceding to the outcome of the sampling technique that was used, 98 people were selected proportionately from passengers of $\mathrm{KM}$ Doralonda (34 people), KM Lawit (32 people), and KM Bukit Raya (32 people).

Data analysis followed several steps. Prior to testing research hypotheses, the following the formula $G=P$ (Mean Percep- 
Wayu Eko Yudiatmaja, Alfiandri and Rahmat Hidayat - Far from Fire: The service delivery....

Table 2. Service delivery received (Data analysis)

\begin{tabular}{lc}
\hline \multicolumn{1}{c}{ Dimension } & Value \\
\hline Reliability & 249 \\
Responsiveness & 237 \\
Assurance & 233 \\
Empathy & 244 \\
Tangibility & 243 \\
Mean & 241 \\
\hline
\end{tabular}

Table 3. Expected service delivery (Data analysis)

\begin{tabular}{lc}
\hline \multicolumn{1}{c}{ Dimension } & Value \\
\hline Reliability & 411 \\
Responsiveness & 421 \\
Assurance & 419 \\
Empathy & 433 \\
Tangibility & 433 \\
Mean & 423 \\
\hline
\end{tabular}

tion) $-E$ (Mean Expectations) was used to determine the service delivery gap. Meanwhile, class intervals were used to interpret analysis results that were obtained from all categories of service delivery. The class interval range included (1) 98-177 (poor), (2) 178-257 (not good), (3) 258-337 (adequate or enough), (4) 338-417 (good), (5) 418-497 (very good). Subsequently, testing hypotheses was done using the formula that; if $\mathrm{x}^{-} E S$ $P S=0$ then $\mathrm{H} 1$ was rejected, but to the contrary if $\mathrm{x} E S-P S \neq 0$ then $\mathrm{H} 1$ was not rejected. The last section presents an analysis of quality (Q) of service delivery obtained by dividing the total mean consumer perception by expectation of each dimension. Hypothesis 2 (H2) was not rejected if $\mathrm{Q}>0$, however if $\mathrm{Q}=0$ or $Q<0$ then $\mathrm{H} 2$ was rejected.

\section{RESULTS AND DISCUSSION}

With regards to the aspect of service delivery received, as is illustrated in table 2, it is evident that the average value of service received (perceived service quality) by passengers who use Sri Bayintan terminal was 241. The value based on class interval speci- fied above, the result indicates that service passengers receive at the terminal falls into the category of 'not good' compared to the expected service delivery (Table 3 ). Research results also showed that all dimensions of service delivery that consist of reliability (249), responsiveness (237), assurance (233), empathy (244), and tangibility (243) had values that fell into class interval of "not good' according to perceptions of passengers of various ships who were surveyed. The implication of then finding is that PT Pelindo I as the manager of Sri Bayintan, Kijang port has been able to deliver services that meet public expectations.

Meanwhile with respect to expected service delivery, passengers of the various ships that were surveyed in the study tended to be very high. This is evident from the high value that responsiveness, assurance, empathy and tangibility dimensions had which was above 418 . In terms of class interval, the dimension of responsiveness (421), assurance (419), empathy (433), and tangibility (433), attested to the fact that passengers had high expectations about the 


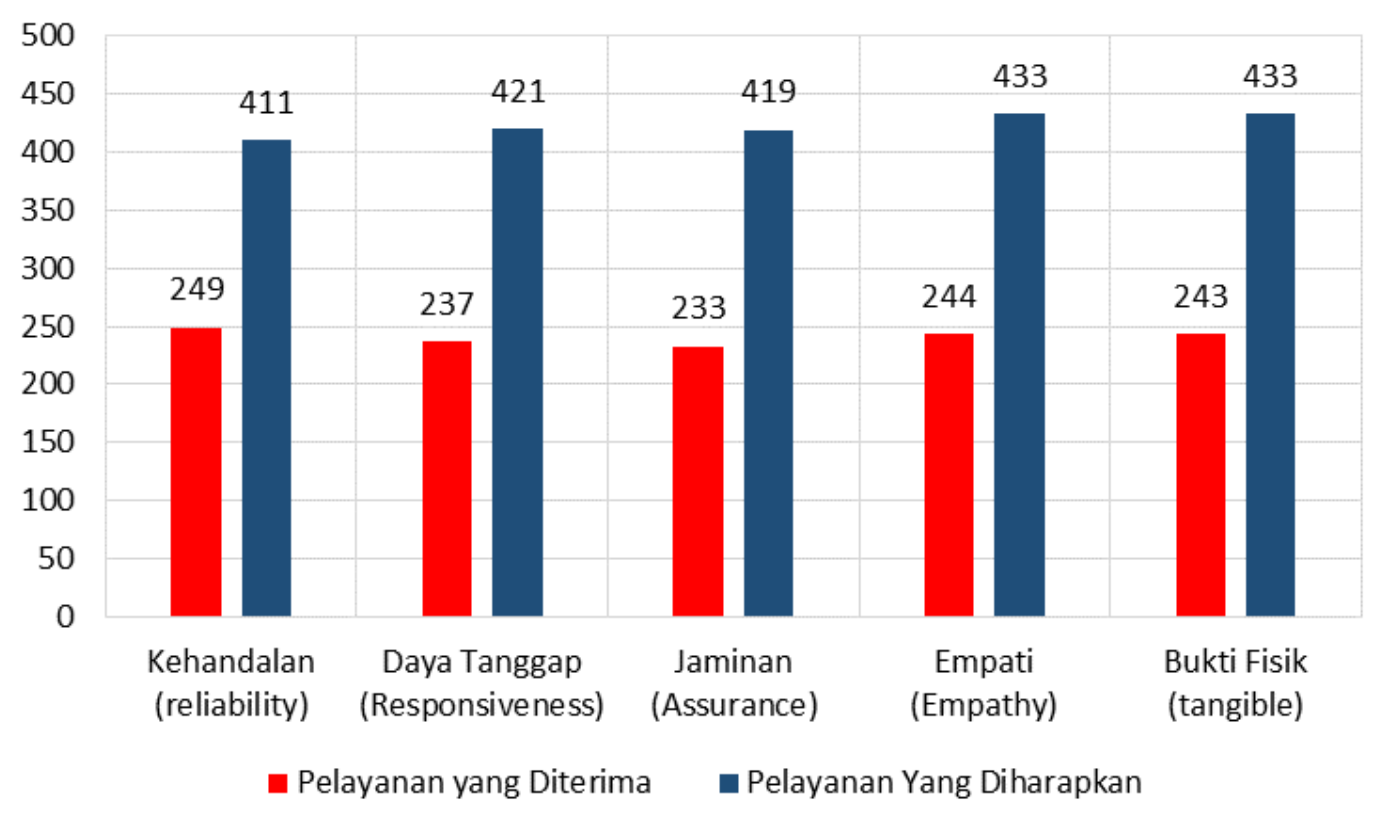

Figure 2. Comparison of received and expected service delivery (Data analysis)

quality of service delivery they would receive as the values of the four dimensions fell into the 'very good' class interval. Nonetheless, with respect to the dimension of reliability, passengers expectations fell into the 'good' category with value of 411 which is lower than 418 . That said, the average the five dimensions with respect to passenger expectations was 423 . The implication of that is that overall, passengers expectations was very good.

Figure 2. Illustrates the comparison between expected and perceived service delivery by service users. Based on the figure 2 , it is evident that there is a gap between the value of service delivery service users received and expected service delivery of service users. From the vantage point of all dimensions such as reliability, responsiveness, assurance, empathy, and tangibility, based on data that this research used, it is evident that there is a gap between perceived service delivery and expected service delivery. The figure below also shows that the value of service delivery passenger received was lower than the value passengers expected to receive. Consequently, PT Pelindo I as the operator of Sri Bayintan has not been able to meet all public needs and requirements in services it provides.

Table 4 shows the magnitude of the gap between service delivery received and service delivery expected. Based on data in table 4, it is evident that all dimensions of service delivery have negative value gaps. In fact the reliability dimension had the largest negative gap that was in the order of 162. The implication is that reliability falls into the class interval of 'very poor'. Meanwhile, from the vantage point of mean value of the gap in expected and received service delivery was -182.2 , which indicates that service quality PT Pulido I delivers to passengers is not good. In accordance with the guidelines that were laid out to test the hypotheses for this research, H1 was not rejected because $x E S-P S \neq 0$. The implication of the foregoing is that $\mathrm{H} 1$ was not rejected (accepted), which provides empirical evidence of the existence of a gap between expected and received service delivery among passengers.

The mean value of the quality of service delivery at Sri Baingan harbor passenger terminal, as shown in table 5, was 0.569. To that end, H2 was not rejected (accepted) because $\mathrm{Q}$ (quality) $>0$. The implication is that passengers were not satisfied with service delivery they received from PT Pelindo I as the manager of Sri Bayintan Kijang port.

To that end, results of this research corroborate findings of a previous research 
Wayu Eko Yudiatmaja, Alfiandri and Rahmat Hidayat — Far from Fire: The service delivery....

Table 4. The Value of the gap (Data analysis)

\begin{tabular}{lccc}
\hline \multicolumn{1}{c}{ Dimension } & $\mathbf{P}$ & $\mathbf{E}$ & $\begin{array}{c}\text { Gap } \\
(\mathbf{G}=\mathbf{P}-\mathbf{E})\end{array}$ \\
\hline Reliability & 249 & 411 & -162 \\
Responsiveness & 237 & 421 & -184 \\
Assurance & 233 & 419 & -186 \\
Empathy & 244 & 433 & -189 \\
Tamgibleness & 243 & 433 & -190 \\
Mean & 241.2 & 423.4 & -182.2 \\
\hline
\end{tabular}

by Parasuraman, Zeithaml, \& Berry (1985, 1988) that identified a gap between expected and perceived service delivery in service delivery of marketing organizations. Findings of this study confirm and lend credence to another research by Pantouvakis (2006) that among other findings, identified high fragmentation and complexity in the dimensions of quality of service delivery in ports that include service delivery, safety, sanitation, communication, guidance, and information. This research also confirms and corroborates findings of a study conducted by Arsanam \& Yousapronpaiboon (2014) that examined customer satisfaction with service provision in government hospitals in Thailand. Moreover, findings of this research are similar to those obtained in study by Arsanam \& Yousapronpaiboon (2014), which found a significant relationship between the quality of service delivery and customer satisfaction.

Results of this support all the findings of a another research conducted by Widihastuti (2003) which found a gap between expected and perceived service delivery in social organizations in Surakarta. The value of the gap was in the order of -0.657 , which means that there is a gap between the quality of expected service expected and received (perceived). Findings of this research are also in line to findings in a research by Hariastuti \& Ardiansyah (2013) on passenger perception about the quality of service delivery in Tanjung Perak passenger terminal, Surabaya. Hariastuti \& Ardiansyah (2013) also found that dimensions of service delivery in Tanjung Perak Surabaya port, such tangibility, responsiveness, assurance, and empathy had negative signs. The mean value of the quality of service delivery in Tanjung Perak Surabaya passenger was in the order of -0.03746 . In other words, high passenger expectations about the quality of service delivery were in stark contrast with the quality of service delivery they received.

Nonetheless, findings in this research are contrary to those obtained in a research conducted by Soamole \& Susanto (2013). The research by Soamole \& Susanto (2013), which discussed the quality of service delivery in Regional Sanana port, and used Importance Performance Analysis (IPA) and Customer Satisfaction Index (CSI), found that the index of customer satisfaction with services delivered was 54.74 present, which falls into the category of adequate. Findings in this research are also dissimilar to results of a research by Andhika (2015), which used quantitative methods to analyze the quality of service delivery in Gapura Surya Nusantara port, which is managed by Tanjung Perak branch, of PT Pelindo III, Surabaya. Andhika (2015) concluded that the quality of service delivery in Gapura Surya Nusantara passenger terminal, gauged from the dimensions of reliability, responsiveness, assurance, empathy, and tangibility .

\section{CONCLUSION}

The purpose of this research was to determine the quality of service delivery and whether or not there is a relationship between perception of quality of service delivery and passenger satisfaction for Sri Bayintan port passengers. Research results 
Table 5. The quality of service delivery received by passengers at Sri Bayintan passenger terminal (Data analysis)

\begin{tabular}{lccc}
\hline \multicolumn{1}{c}{ Dimension } & Actual (P) & $\begin{array}{c}\text { Expecta- } \\
\text { tion (E) }\end{array}$ & $Q=\frac{P}{E}$ \\
\hline Reliability & 249 & 411 & 0.606 \\
Responsiveness & 237 & 421 & 0.563 \\
Assurance & 233 & 419 & 0.556 \\
Empathy & 244 & 433 & 0.564 \\
Tangibility & 243 & 433 & 0.561 \\
Mean & 241.2 & 423.4 & 0.569 \\
\hline
\end{tabular}

showed that there is a gap between the quality of expected and received (perceived) service delivery among passengers of Sri Bayintan passenger terminal. The implication of the finding is that the quality of service delivery for passengers of Sri Bayintan port falls far short of passenger /public expectations. Research findings prove and support the theory propounded by Parasuraman, Zeithaml, \& Berry $(1985,1988)$ on the existence of a gap between service delivery which has the potential to undermine the quality of service delivery. One the gaps relates to the disparity between the expected and received (perceived) service delivery. The existence of the gap underscores the fact that passenger perception about the quality of services received is incongruent with the expected quality of service delivery.

\section{REFERENCES}

Agus, A., Barker, S., \& Kandampully, J. (2007). An exploratory study of service quality in the Malaysian public service sector. International Journal of Quality \& Reliability Management, 24(2), 177190.

Andhika, S. N. (2015). Kualitas pelayanan jasa terminal penumpang Gapura Surya Nusantara pada PT Pelindo III (Persero) Cabang Tanjung Perak Surabaya [Service quality passengers of Gapura Surya Nusantara on PT Pelindo III (Persero) Branch of Tanjung Perak, Surabaya]. Jurnal Mahasiswa Teknologi Pendidikan, 10(1), 1-20.

Ansah, E. E. (2008). Investigating the role of service interactions in perceptions of service quality: The case of the Ghanaian public sector. Ph.D Thesis in The State University of New Jersey.

Arsanam, P., \& Yousapronpaiboon, K. (2014). The relationship between service quality and customer satisfaction of pharmacy departments in public hospitals. International Journal of Innovation, Management and Technology, 5 (4), 261-265.

Berry, L. L. et al. (1994). Improving service quality in America : Lessons leared and executive commentary. Academy of Management Executive, 8(2), 32-52.

Boyne, G. A. (2002). Public and private management: What's the difference? Journal of Management Studies, 39(1), 97-122.

Brown, S. W., \& Swartz, T. A. (1989). A gap analysis of professional service quality. Journal of Marketing, 53(2), 92 -98 .

Brown, T., Churchill, G., \& Peter, P. (1993). Improving the measurement of service quality. Journal of Retailing, 69(1), 127 -139 .

Brysland, A., \& Curry, A. (2001). Service improvements in public services using SERVQUAL. Managing Service Quality, 11(6), 389-401.

Clements, M. E. (2001). Local telephone quality-of-service: The impact of regulation and competition. Ph.D Thesis in The Ohio State University.

Curry, A., \& Sinclair, E. (2002). Assessing the quality of physiotherapy services using Servqual. International Journal of 
Wayu Eko Yudiatmaja, Alfiandri and Rahmat Hidayat - Far from Fire: The service delivery....

Health Care Quality Assurance, 15, 197-205.

Denhadrt, J. V, \& Denhardt, R. B. (2007). The new public service: Serving, not steering, expanded edition. Armonk, NY: M.E. Sharpe.

Dick, A. A., \& Dick, A. A. (2007). Market size, service quality, and competition in banking. Journal of Money, Credit and Banking, 39(1), 49-81.

Donnelly, M. et al. (1995). Measuring service quality in local government: The SERVQUAL approach. International Journal of Public Sector Management, $8(7), 15-20$.

Ferlie, E. et al. (1996). The new public management in action. Oxford: Oxford University Press.

Giannoccaro, R. et al. (2008). Measuring citizen satisfaction with aspects of public services from a local authority and determining their importance: A case study. Public Organization Review, 8 (1), 1-15.

Grönroos, C. (1984). A service quality model and its marketing implications. European Journal of Marketing, 18(4), 3644.

Hariastuti, N. L. P., \& Ardiansyah, D. R. (2013). Peningkatan kualitas layanan kepada pelanggan di terminal penumpang Pelabuhan Tanjung Perak Surabaya [Improving customers service quality at passenger terminal in Tanjung Perak Port, Surabaya]. Jurnal Ilmiah Teknik Industri, 12(2), 192-200.

Hartley, J., \& Skelcher, C. (2008). The agenda for public service improvement. In J. Hartley, C. Donaldson, C. Skelcher, \& M. Wallace (Eds.), Managing to improve public services (pp. 3-23). Cambridge: Cambridge University Press.

Jakka, A. A. (2004). Client-quality dimensions: Empirical evidence from the public sector of the United Arab Emirates. Public Organization Review, 4(3), 239-257.

Kettl, D. F. (2000). The global public management revolution. Washington, D.C.: Brookings Institution Press.

Kim, Y. (2004). Managing and assessing Internet service needs and use of underserved populations at public libraries. In Proceedings of the ASIST Annual
Meeting (Vol. 41, pp. 479-487).

Lachman, R. (1985). Public and private sector differences: CEOs' perceptions of their role environments. Academy of Management Journal, 28(3), 671-680.

Lewis, B. D., \& Pattinasarany, D. (2009). Determining citizen satisfaction with local public education in Indonesia: The significance of actual service quality and governance conditions. Growth and Change, 40(1), 85-115.

Malhotra, N. K. et al. (2005). Dimensions of service quality in developed and developing economies: multi-country crosscultural comparisons. International Marketing Review, 22(3), 256-278.

McKoy, D. V. (2004). The new public management in Jamaica: Executive agencies and service quality delivery in public sector reforms. Ph.D Thesis in Nova Southeastern University.

Moulton, S., \& Wise, C. (2010). Shifting boundaries between the public and private sectors: Implications from the economic crisis. Public Administration Review, 70(3), 349-360.

Murray, M. A. (1975). Comparing public and private management: An exploratory Essay. Public Administration Review, 35(4), 364-371.

Najjar, L., \& Bishu, R. R. (2006). Service quality : A case study of a bank. Quality Management Journal, 13(3), 35-44.

Orwig, R. A., Pearson, J., \& Cochran, D. (1997). An empirical investigation into the validity of SERVQUAL in the public sector. Public Administration Quarterly, 21(1), 54-68.

Osborne, D., \& Gaebler, T. (1992). Reinventing government: How the entrepreneurial spirit is transforming the Public Sector. Reading, MA: Addison-Wesley.

Osborne, D., \& Plastrik, P. (1997). Banishing bureaucracy: The five strategies for reinventing government. Reading, MA: Addison-Wesley.

Pantouvakis, A. (2006). Port-service quality dimensions and passenger profiles: An exploratory examination and analysis. Maritime Economics \& Logistics, 8(4), 402-418.

Pantouvakis, A., Chlomoudis, C., \& Dimas, A. (2008). Testing the SERVQUAL scale in the passenger port industry: A 
confirmatory study. Maritime Policy \& Management, 35(5), 449-467.

Pantouvakis, A., \& Lymperopoulos, K. (2008). Customer satisfaction and loyalty in the eyes of new and repeat customers: Evidence from the transport sector. Managing Service Quality, 18 (6), 623-643.

Parasuraman, A., Berry, L. L., \& Zeithaml, V. A. (1991). Refinement and reassessment of the SERVQUAL Scale. Journal of Retailing, 67(4), 420-450.

Parasuraman, A., Zeithaml, V. A., \& Berry, L. L. (1985). A conceptual model service quality and its implications for future research. Journal of Marketing, 49 (4), 41-50.

Parasuraman, A., Zeithaml, V. A., \& Berry, L. L. (1988). SERVQUAL: A multipleitem scale for measuring consumer Perceptions of service quality. Journal of Retailing, 64(1), 12-40.

Parasuraman, A., Zeithaml, V. A., \& Berry, L. L. (1993). More on improving service quality measurement. Journal of Retailing.

Pérez, M. S. et al. (2007). Effects of service quality dimensions on behavioural purchase intentions: A study in publicsector transport. Managing Service Quality, 17(2), 134-151.

Pinar, M., \& Eser, Z. (2008). Examining the bank service quality from personnel point of view: The comparisons of state, private and foreign banks in Turkey. The Business Review, 10(2), 2734.

Pramusinto, A. (2006). Inovasi-inovasi pelayanan publik untuk pengembangan ekonomi lokal: Pengalaman beberapa daerah [Innovations of public service for developing local economy: Experience from some regions]. JKAP (Jurnal Kebijakan Dan Administrasi Publik), 10(1), 1-18.

Rainey, H. G., Backoff, R. W., \& Levine, C. H. (1976). Comparing public and private organizations. Public Administration Review, 36(2), 233-244.

Rainey, H. G., \& Bozeman, B. (2000). Comparing public and private organizations: Empirical research and the power of the a priori. Journal of Public Administration Research and Theory, 10(2), 447-
469.

Rhee, S.-K., \& Rha, J.-Y. (2009). Public service quality and customer satisfaction: Exploring the attributes of service quality in the public sector. Service Industries Journal, 29(11), 1491-1512.

Rowley, J. (1998). Quality measurement in the public sector: Some perspectives from the service quality literature. Total Quality Management, 9(2/3), 321-333.

Shah, A. (2005). Public services delivery: Public sector governance and accountability series. The World Bank. Washington, D.C.

Soamole, B., \& Susanto, B. (2013). Analisis persepsi penumpang terhadap kualitas pelayanan angkutan laut di Pelabuhan Regional Sanana Kab. Kepulauan Sula, Provinsi Maluku Utara [Analyzing perceptions of passengers on quality service of sea transportation at Regional Port of Sanana Sula Islands, North Maluku]. Jurnal Teknik Sipil, 12(3), 202 209.

Taylor, F. W. (1947). Scientific management. New York: Harper and Row.

Tejada, J. J., \& Punzalan, J. R. B. (2012). On the misuse of Slovin's formula. The Philippine Statistician, 61(1), 129-136.

Ugboma, C., Ibe, C., \& Ogwude, I. C. (2004). Service quality measurements in ports of a developing economy: Nigerian ports survey. Managing Service Quality, 14(6), 487-495.

Ugboma, C. et al. (2007). Service quality and satisfaction measurements in Nigerian ports: An exploration. Maritime Policy \& Management, 34(4), 331-346.

White, L. D. (1926). Introduction to the study of public administration. New York: Macmillan.

Widaningrum, A. (2007). Bekerjanya desentralisasi pada pelayanan publik [Working decentralization in public services]. JKAP (Jurnal Kebijakan Dan Administrasi Publik), 11(1), 43-60.

Widihastuti, I. (2003). Evaluasi kualitas pelayanan organisasi sosial dengan metode SERVQUAL di Kota Surakarta: Studi pada organisasi sosial yang memberikan pelayanan kesejahteraan sosial [Evaluating quality service of social organizations with SERVQUAL method in Surakarta City]. Master Thesis in 
Wayu Eko Yudiatmaja, Alfiandri and Rahmat Hidayat - Far from Fire: The service delivery....

Diponegoro University, Semarang.

Willoughby, W. F. (1927). Principles of public administration. Baltimore: Johns Hopkins University Press.

Wisniewski, M. (2001). Using servqual to assess customer satisfaction with public sector services. Managing Service Quality, 11(6), 380-388.

Wisniewski, M., \& Donnelly, M. (1996). Measuring service quality in the public sector: The potential for SERVQUAL. Total Quality Management, 7(4), 357365.

Yousapronpaiboon, K. (2014). SERVQUAL: Measuring higher education eervice quality in Thailand. In Procedia - Social and Behavioral Sciences (Vol. 116, pp. 1088-1095).

Yousapronpaiboon, K., \& Johnson, W. C. (2013a). A Comparison of service quality between private and public hospitals in Thailand. International Journal of Business and Social Science, 4(11), 176 -184 .
Yousapronpaiboon, K., \& Johnson, W. C. (2013b). Measuring hospital out-patient service quality in Thailand. Leadership in Health Services, 26(4), 338-355.

Yousapronpaiboon, K., \& Johnson, W. C. (2013c). Out-patient service quality perceptions in private Thai hospitals. International Journal of Business and Social Science, 4(2), 57-66.

Yudiatmaja, W. E. (2012). Dinamika administrasi negara kontemporer: Konsep dan isu [The Dynamics of contemporary public administration: Concepts and Issues]. Yogyakarta: Capiya Publishing.

Zeithaml, V. A. (2002). Service excellence in electronic channels. Managing Service Quality, 12(3), 135-139.

Zeithaml, V. A., Parasuraman, A., \& Berry, L. L. (1990). Delivering quality service: Balancing customer perceptions and expectations. New York: The Free Press 